\title{
IMPLEMENTASI DATA MINING UNTUK MENGETAHUI MANFAAT RPTRA MENGGUNAKAN METODE K-MEANS CLUSTERING
}

\author{
Ditta Sri Wardiani' ${ }^{1}$, Nita Merlina ${ }^{2}$ \\ Sistem Informasi \\ STMIK Nusa Mandiri \\ http://nusamandiri.ac.id \\ 1dittasriw@gmail.com
Sistem Informasi Kampus Kota Sukabumi
Universitas Bina Sarana Informatika
http://bsi.ac.id/ubsi
2nita@nusamandiri.ac.id

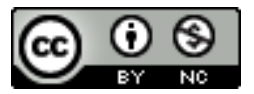

Ciptaan disebarluaskan di bawah Lisensi Creative Commons Atribusi-NonKomersial 4.0 Internasional.

\begin{abstract}
The vacant land in DKI Jakarta is increasingly reducing due to the construction of houses, queues, factories, which are increasingly rapid. Making less green open space and water catchment areas. That way, the park of the children to play even decreases, as well as the DKI Jakarta Provincial Government, decides to make a ChildFriendly Integrated Public Room or what we know as RPTRA with facilities that can help the community around it. With this RPTRA, the public especially children can play and interact with each other. Using the K-Means Clustering method can help the government or officers in each RPTRA more easily see how useful this RPTRA and the government also facilitates some of the rooms contained in this RPTRA namely the hall, library, and playroom. The results of this research are the hall that has the highest value for visitors who come where the value obtained is 1319 visitors.
\end{abstract}

Keywords : DKI Jakarta, RPTRA, Data Mining, Clustering

Intisari-Lahan kosong yang terdapat di DKI Jakarta ini semakin mengurang karena pembangunan rumah, kantor, pabrik dll yang semakin pesat. Membuat berkurangnya ruang terbuka hijau dan daerah resapan air. Dengan begitu taman untuk biasanya anak-anak bermainpun ikut berkurang juga. Pemrov DKI Jakarta memutuskan untuk membuat Ruang Publik Terpadu Ramah Anak atau yang kita kenal dengan sebutan RPTRA dengan fasilitas-fasilitas yang dapat membantu masyarakat disekitarnya. Dengan RPTRA ini umumnya masyarakat khususnya anak-anak dapat bermain dan saling berinteraksi dengan yang lainnya. Menggunakan metode K-Means Clustering dapat membantu pemerintah ataupun petugas pada setiap RPTRA lebih mudah melihat seberapa bermanfaatnya RPTRA ini. Dan pemerintah juga memfasilitasi beberapa ruangan yang terdapat di RPTRA ini yaitu Ruang Aula, Ruang Perpustakaan dan Ruang Bermain. Hasil penelitian ini adalah ruang aula yg memiliki nilai tertinggi untuk pengunjung yang dating dimana nilai yang didapat adalah 1319 pengunjung .

Kata Kunci : DKI Jakarta, RPTRA, Data Mining, Clustering

\section{PENDAHULUAN}

Kehidupan yang semakin meningkat, pembangunan dimana-mana, membuat DKI Jakarta kini semakin padat. Kurangnya lahan resapan air (Sanitya \& Burhanudin, 2013), kurangnya ruang terbuka hijau (Indah, Wardiyati, \& Setyobudi, 2014), ruang terbuka bagi publik maupun ruang edukasi yang umum bisa dimanfaatkan bagi siapa saja menjadi suatu masalah bagi kehidupan sosial masyarakat Jakarta sebagai dampak keadaan lingkungan fisik tersebut. Dengan banyaknya masalah ini, sehingga menjadi tugas untuk Pemprov DKI Jakarta agar dapat menyelesaikan masalah ini. Pemerintah Provinsi DKI Jakarta memutuskan untuk membangun lahan terbuka hijau dan ruang publik terbuka untuk masyarakat salah satunya yaitu RPTRA. RTH berfungsi sebagai penyeimbang pembangunan kota, khususnya dalam menanggulangi banjir, menyerap polutan, dan 
menyuplai oksigen. Berkurangnya jumlah ruang terbuka hijau di Jakarta (Rosyidin, W. F., Giyanti, S., \& Dahlia, 2017) Harapannya agar DKI Jakarta dapat meraih predikat salah satu kota layak anak. RPTRA sendiri adalah kependekan dari Ruang Publik Terpadu Ramah Anak. Dengan mengusung tema ruang hijau dan taman yang sangat menarik untuk anak-anak dilengkapi dengan taman bermain, serta ruang perpustakaan dan ruangruang lainnya. Sejauh ini telah dibangun beberapa RPTRA di penjuru Jakarta agar semakin banyaknya ruang terbuka hijau dan membuat asri DKI Jakarta ini. Fasilitas-fasilitas yang dibutuhkan oleh masyarakat sekitar, menjadikan RPTRA ini menjadi tempat untuk berkumpul, tempat bermain anak-anak, dan bahkan hingga tempat untuk berolahraga. Dilihat dari kegunaannya RPTRA sendiri sangat penting, sehingga dengan adanya penelitian ini dapat membantu pemerintah dalam melihat manfaat RPTRA dan meneglompokkannya menjadi 3 ruang yang paling sering diminati oleh pengunjung. Maka dari itu diperlukan suatu proses pengklasteran data (Prasetyowati \& Rofiq, 2016) ruangan dengan menggunakan suatu teknik data mining. Teknik data mining yang akan digunakan pada penelitian ini adalah clustering dengan pendekatan metode $K$-Means (Suwardika, 2017).

\section{BAHAN DAN METODE}

Dalam penelitian ini menggunakan design penelitian deskriptif sederhana yang merupakan jenis penelitian yang bertujuan untuk mengetahui gambaran atau deskripsi tentang suatu keadaan secara objektif (Sugiyono, 2014). Dalam penelitian ini penulis menggunakan data mining dalam proses untuk menggali nilai tambah berupa informasi yang selama ini tidak diketahui secara manual dari suatu data. (Vulandari, 2017).

Sedangkan K-Means merupakan metode yang digunakan dalam algoritma clustering berbasis jarak yang membagi data ke dalam sejumlah cluster dan algoritma ini hanya bekerja pada atribut numerik. (Dhuhita, 2016) dan untuk menunjang pengolahan data maka penulis menggunakan program spreadsheet (Wicaksono Yudhy \& Solusi Kantor, 2017)

\section{A. Rancangan Penelitian}

Langkah-langkah penelitian ini adalah sebagai berikut :

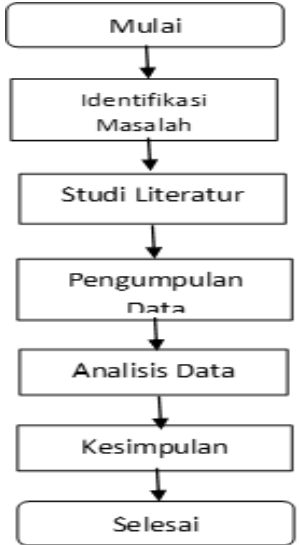

Sumber: (Wardiani \& Merlina, 2018)

Gambar 1. Tahapan Penelitian

B. Sumber Data dan teknik pengumpulan data

Populasi dari penelitian ini adalah masyarakat sekitar RPTRA Kampung Benda sedangkan sample dari penelitian ini adalah menggunakan Random Sample.

\section{Analisis Data}

Untuk mencapai tujuan penelitian maka analisis yang digunakan adalah analisis data kuantitatif yang dimana merupakan suatu analisa data yang digunakan apabila kesimpulankesimpulan yang diperoleh dapat dibuktikan dengan angka-angka dan juga dalam perhitungan dipergunakan rumus yang ada hubungannya dengan penulisan. Dalam hal ini akan dipergunakan analisa K-Means Clustering.

Penulis mengambil 3 ruangan yang terdiri dari Ruang Aula, Ruang Perpustakaan dan Ruang Bermain dengan waktu penelitian 2 bulan. Adapun data dari 3 ruangan tersebut sebagai berikut :

\section{Ruang Aula Bulan April - mei 2018}

Tabel 1. Data Aula 1

\begin{tabular}{cccc}
\hline Hari / & Jumlah & $\begin{array}{c}\text { Hari / } \\
\text { Tanggal }\end{array}$ & Jumlah \\
Tanggal & 32 & Selasa, 1 Mei & 33 \\
Minggu, 1 April & pengunjung & 2018 & pengunjung \\
2018 & 36 & Rabu, 2 Mei & 24 \\
Senin, 2 April & pengunjung & 2018 & pengunjung \\
2018 & 41 & Kamis, 3 Mei & 14 \\
Selasa, 3 April & pengunjung & 2018 & pengunjung \\
2018 & 38 & Jumat, 4 Mei & 24 \\
\hline Rabu, 4 April & pengunjung & 2018 & pengunjung \\
2018 & 33 & Sabtu, 5 Mei & 46 \\
Kamis, 5 April & pengunjung & 2018 & pengunjung \\
2018 & 45 & Minggu, 6 & 21 \\
\hline Jumat, 6 April & pengunjung & Mei 2018 & pengunjung \\
2018 & 29 & Senin, 7 Mei & 41 \\
\hline Sabtu, 7 April & pengunjung & 2018 & pengunjung \\
2018 & 39 & Selasa, 8 Mei & 62 \\
\hline Minggu, 8 April & pengunjung & 2018 & pengunjung \\
2018 & 29 & Rabu, 9 Mei & 33 \\
\hline Senin, 9 April & pengunjung & 2018 & pengunjung \\
\hline 2018 & & &
\end{tabular}




\begin{tabular}{|c|c|c|c|}
\hline $\begin{array}{c}\text { Hari / } \\
\text { Tanggal }\end{array}$ & Jumlah & $\begin{array}{c}\text { Hari / } \\
\text { Tanggal }\end{array}$ & Jumlah \\
\hline $\begin{array}{c}\text { Selasa, } 10 \text { April } \\
2018\end{array}$ & $\begin{array}{c}26 \\
\text { pengunjung }\end{array}$ & $\begin{array}{l}\text { Kamis, } 10 \\
\text { Mei } 2018\end{array}$ & $\begin{array}{c}52 \\
\text { pengunjung }\end{array}$ \\
\hline $\begin{array}{c}\text { Rabu, 11 April } \\
2018\end{array}$ & $\begin{array}{c}36 \\
\text { pengunjung }\end{array}$ & $\begin{array}{l}\text { Jumat, } 11 \\
\text { Mei } 2018 \\
\end{array}$ & $\begin{array}{c}37 \\
\text { pengunjung }\end{array}$ \\
\hline $\begin{array}{c}\text { Kamis, } 12 \text { April } \\
2018\end{array}$ & $\begin{array}{c}121 \\
\text { pengunjung }\end{array}$ & $\begin{array}{c}\text { Sabtu, } 12 \text { Mei } \\
2018\end{array}$ & $\begin{array}{c}20 \\
\text { pengunjung }\end{array}$ \\
\hline $\begin{array}{c}\text { Jumat, } 13 \text { April } \\
2018\end{array}$ & $\begin{array}{c}14 \\
\text { pengunjung }\end{array}$ & $\begin{array}{l}\text { Minggu, } 13 \\
\text { Mei } 2018\end{array}$ & $\begin{array}{c}51 \\
\text { pengunjung }\end{array}$ \\
\hline $\begin{array}{c}\text { Sabtu, 14 April } \\
2018\end{array}$ & $\begin{array}{c}40 \\
\text { pengunjung }\end{array}$ & $\begin{array}{c}\text { Senin, 14 Mei } \\
2018\end{array}$ & $\begin{array}{c}46 \\
\text { pengunjung }\end{array}$ \\
\hline $\begin{array}{l}\text { Minggu, } 15 \\
\text { April } 2018 \\
\end{array}$ & $\begin{array}{c}51 \\
\text { pengunjung }\end{array}$ & $\begin{array}{l}\text { Selasa, } 15 \\
\text { Mei } 2018 \\
\end{array}$ & $\begin{array}{c}48 \\
\text { pengunjung }\end{array}$ \\
\hline $\begin{array}{c}\text { Senin, } 16 \text { April } \\
2018\end{array}$ & $\begin{array}{c}25 \\
\text { pengunjung }\end{array}$ & $\begin{array}{c}\text { Rabu, } 16 \text { Mei } \\
2018\end{array}$ & $\begin{array}{c}26 \\
\text { pengunjung }\end{array}$ \\
\hline $\begin{array}{c}\text { Selasa, } 17 \text { April } \\
2018\end{array}$ & $\begin{array}{c}37 \\
\text { pengunjung }\end{array}$ & $\begin{array}{l}\text { Kamis, } 17 \\
\text { Mei } 2018\end{array}$ & $\begin{array}{c}29 \\
\text { pengunjung }\end{array}$ \\
\hline $\begin{array}{c}\text { Rabu, 18 April } \\
2018\end{array}$ & $\begin{array}{c}29 \\
\text { pengunjung }\end{array}$ & $\begin{array}{l}\text { Jumat, } 18 \\
\text { Mei } 2018\end{array}$ & $\begin{array}{c}60 \\
\text { pengunjung }\end{array}$ \\
\hline $\begin{array}{c}\text { Kamis, } 19 \text { April } \\
2018\end{array}$ & $\begin{array}{c}29 \\
\text { pengunjung }\end{array}$ & $\begin{array}{c}\text { Sabtu, 19 Mei } \\
2018\end{array}$ & $\begin{array}{c}34 \\
\text { pengunjung }\end{array}$ \\
\hline $\begin{array}{c}\text { Jumat, } 20 \text { April } \\
2018\end{array}$ & $\begin{array}{c}60 \\
\text { pengunjung }\end{array}$ & $\begin{array}{c}\text { Minggu, } 20 \\
\text { Mei } 2018\end{array}$ & $\begin{array}{c}47 \\
\text { pengunjung }\end{array}$ \\
\hline $\begin{array}{c}\text { Sabtu, 21 April } \\
2018\end{array}$ & $\begin{array}{c}32 \\
\text { pengunjung }\end{array}$ & $\begin{array}{c}\text { Senin, } 21 \text { Mei } \\
2018\end{array}$ & $\begin{array}{c}59 \\
\text { pengunjung }\end{array}$ \\
\hline $\begin{array}{l}\text { Minggu, } 22 \\
\text { April } 2018\end{array}$ & $\begin{array}{c}37 \\
\text { pengunjung }\end{array}$ & $\begin{array}{l}\text { Selasa, } 22 \\
\text { Mei } 2018\end{array}$ & $\begin{array}{c}52 \\
\text { pengunjung }\end{array}$ \\
\hline $\begin{array}{c}\text { Senin, } 23 \text { April } \\
2018\end{array}$ & $\begin{array}{c}59 \\
\text { pengunjung }\end{array}$ & $\begin{array}{c}\text { Rabu, 23 Mei } \\
2018\end{array}$ & $\begin{array}{c}21 \\
\text { pengunjung }\end{array}$ \\
\hline $\begin{array}{c}\text { Selasa, } 24 \text { April } \\
2018 \\
\end{array}$ & $\begin{array}{c}56 \\
\text { pengunjung }\end{array}$ & $\begin{array}{l}\text { Kamis, } 24 \\
\text { Mei } 2018\end{array}$ & $\begin{array}{c}43 \\
\text { pengunjung }\end{array}$ \\
\hline $\begin{array}{c}\text { Rabu, } 25 \text { April } \\
2018\end{array}$ & $\begin{array}{c}57 \\
\text { pengunjung }\end{array}$ & $\begin{array}{l}\text { Jumat, } 25 \\
\text { Mei } 2018 \\
\end{array}$ & $\begin{array}{c}24 \\
\text { pengunjung }\end{array}$ \\
\hline $\begin{array}{c}\text { Kamis, } 26 \text { April } \\
2018 \\
\end{array}$ & $\begin{array}{c}32 \\
\text { pengunjung }\end{array}$ & $\begin{array}{c}\text { Sabtu, } 26 \text { Mei } \\
2018 \\
\end{array}$ & $\begin{array}{c}23 \\
\text { pengunjung }\end{array}$ \\
\hline $\begin{array}{c}\text { Jumat, } 27 \text { April } \\
2018 \\
\end{array}$ & $\begin{array}{c}65 \\
\text { pengunjung }\end{array}$ & $\begin{array}{l}\text { Minggu, } 27 \\
\text { Mei } 2018 \\
\end{array}$ & $\begin{array}{c}41 \\
\text { pengunjung }\end{array}$ \\
\hline $\begin{array}{c}\text { Sabtu, } 28 \text { April } \\
2018\end{array}$ & $\begin{array}{c}12 \\
\text { pengunjung }\end{array}$ & $\begin{array}{c}\text { Senin, } 28 \text { Mei } \\
2018\end{array}$ & $\begin{array}{c}57 \\
\text { pengunjung }\end{array}$ \\
\hline $\begin{array}{l}\text { Minggu, } 29 \\
\text { April } 2018\end{array}$ & $\begin{array}{c}46 \\
\text { pengunjung }\end{array}$ & $\begin{array}{l}\text { Selasa, } 29 \\
\text { Mei } 2018\end{array}$ & $\begin{array}{c}38 \\
\text { pengunjung }\end{array}$ \\
\hline \multirow[t]{2}{*}{$\begin{array}{c}\text { Senin, } 30 \text { April } \\
2018\end{array}$} & $\begin{array}{c}52 \\
\text { pengunjung }\end{array}$ & $\begin{array}{c}\text { Rabu, } 30 \text { Mei } \\
2018\end{array}$ & $\begin{array}{c}31 \\
\text { pengunjung }\end{array}$ \\
\hline & & $\begin{array}{l}\text { Kamis, } 31 \\
\text { Mei } 2018\end{array}$ & $\begin{array}{c}42 \\
\text { pengunjung }\end{array}$ \\
\hline
\end{tabular}

Sumber: (Wardiani \& Merlina, 2018)

\begin{tabular}{|c|c|c|c|}
\hline $\begin{array}{c}\text { Hari / } \\
\text { Tanggal }\end{array}$ & Jumlah & $\begin{array}{c}\text { Hari / } \\
\text { Tanggal }\end{array}$ & Jumlah \\
\hline $\begin{array}{c}\text { Minggu, } 8 \\
\text { April } 2018 \\
\end{array}$ & $\begin{array}{c}29 \\
\text { pengunjung }\end{array}$ & $\begin{array}{c}\text { Selasa, } 8 \text { Mei } \\
2018\end{array}$ & $\begin{array}{c}31 \\
\text { pengunjung }\end{array}$ \\
\hline $\begin{array}{c}\text { Senin, } 9 \\
\text { April } 2018\end{array}$ & $\begin{array}{c}49 \\
\text { pengunjung }\end{array}$ & $\begin{array}{c}\text { Rabu, } 9 \text { Mei } \\
2018\end{array}$ & $\begin{array}{c}23 \\
\text { pengunjung }\end{array}$ \\
\hline $\begin{array}{c}\text { Selasa, } 10 \\
\text { April } 2018\end{array}$ & $\begin{array}{c}52 \\
\text { pengunjung }\end{array}$ & $\begin{array}{l}\text { Kamis, } 10 \\
\text { Mei } 2018\end{array}$ & $\begin{array}{c}21 \\
\text { pengunjung }\end{array}$ \\
\hline $\begin{array}{c}\text { Rabu, } 11 \\
\text { April } 2018\end{array}$ & $\begin{array}{c}49 \\
\text { pengunjung }\end{array}$ & $\begin{array}{l}\text { Jumat, } 11 \\
\text { Mei } 2018\end{array}$ & $\begin{array}{c}34 \\
\text { pengunjung }\end{array}$ \\
\hline $\begin{array}{c}\text { Kamis, } 12 \\
\text { April } 2018\end{array}$ & $\begin{array}{c}12 \\
\text { pengunjung }\end{array}$ & $\begin{array}{c}\text { Sabtu, } 12 \text { Mei } \\
2018\end{array}$ & $\begin{array}{c}25 \\
\text { pengunjung }\end{array}$ \\
\hline $\begin{array}{c}\text { Jumat, } 13 \\
\text { April } 2018\end{array}$ & $\begin{array}{c}19 \\
\text { pengunjung }\end{array}$ & $\begin{array}{c}\text { Minggu, } 13 \\
\text { Mei } 2018\end{array}$ & $\begin{array}{c}18 \\
\text { pengunjung }\end{array}$ \\
\hline $\begin{array}{c}\text { Sabtu, } 14 \\
\text { April } 2018\end{array}$ & $\begin{array}{c}25 \\
\text { pengunjung }\end{array}$ & $\begin{array}{c}\text { Senin, } 14 \text { Mei } \\
2018\end{array}$ & $\begin{array}{c}49 \\
\text { pengunjung }\end{array}$ \\
\hline $\begin{array}{l}\text { Minggu, } 15 \\
\text { April } 2018\end{array}$ & $\begin{array}{c}31 \\
\text { pengunjung }\end{array}$ & $\begin{array}{l}\text { Selasa, } 15 \\
\text { Mei } 2018\end{array}$ & $\begin{array}{c}48 \\
\text { pengunjung }\end{array}$ \\
\hline $\begin{array}{c}\text { Senin, } 16 \\
\text { April } 2018\end{array}$ & $\begin{array}{c}26 \\
\text { pengunjung }\end{array}$ & $\begin{array}{c}\text { Rabu, } 16 \text { Mei } \\
2018\end{array}$ & $\begin{array}{c}14 \\
\text { pengunjung }\end{array}$ \\
\hline $\begin{array}{c}\text { Selasa, } 17 \\
\text { April } 2018\end{array}$ & $\begin{array}{c}39 \\
\text { pengunjung }\end{array}$ & $\begin{array}{l}\text { Kamis, } 17 \\
\text { Mei } 2018\end{array}$ & $\begin{array}{c}18 \\
\text { pengunjung }\end{array}$ \\
\hline $\begin{array}{c}\text { Rabu, } 18 \\
\text { April } 2018\end{array}$ & $\begin{array}{c}41 \\
\text { pengunjung }\end{array}$ & $\begin{array}{l}\text { Jumat, } 18 \\
\text { Mei } 2018\end{array}$ & $\begin{array}{c}17 \\
\text { pengunjung }\end{array}$ \\
\hline $\begin{array}{c}\text { Kamis, } 19 \\
\text { April } 2018\end{array}$ & $\begin{array}{c}27 \\
\text { pengunjung }\end{array}$ & $\begin{array}{c}\text { Sabtu, } 19 \text { Mei } \\
2018\end{array}$ & $\begin{array}{c}23 \\
\text { pengunjung }\end{array}$ \\
\hline $\begin{array}{c}\text { Jumat, } 20 \\
\text { April } 2018\end{array}$ & $\begin{array}{c}57 \\
\text { pengunjung }\end{array}$ & $\begin{array}{c}\text { Minggu, } 20 \\
\text { Mei } 2018\end{array}$ & $\begin{array}{c}29 \\
\text { pengunjung }\end{array}$ \\
\hline $\begin{array}{c}\text { Sabtu, } 21 \\
\text { April } 2018\end{array}$ & $\begin{array}{c}21 \\
\text { pengunjung }\end{array}$ & $\begin{array}{c}\text { Senin, } 21 \text { Mei } \\
2018\end{array}$ & $\begin{array}{c}10 \\
\text { pengunjung }\end{array}$ \\
\hline $\begin{array}{l}\text { Minggu, } 22 \\
\text { April } 2018\end{array}$ & $\begin{array}{c}37 \\
\text { pengunjung }\end{array}$ & $\begin{array}{l}\text { Selasa, } 22 \\
\text { Mei } 2018\end{array}$ & $\begin{array}{c}27 \\
\text { pengunjung }\end{array}$ \\
\hline $\begin{array}{c}\text { Senin, } 23 \\
\text { April } 2018\end{array}$ & $\begin{array}{c}14 \\
\text { pengunjung }\end{array}$ & $\begin{array}{c}\text { Rabu, } 23 \text { Mei } \\
2018\end{array}$ & $\begin{array}{c}48 \\
\text { pengunjung }\end{array}$ \\
\hline $\begin{array}{c}\text { Selasa, } 24 \\
\text { April } 2018\end{array}$ & $\begin{array}{c}23 \\
\text { pengunjung }\end{array}$ & $\begin{array}{l}\text { Kamis, } 24 \\
\text { Mei } 2018\end{array}$ & $\begin{array}{c}22 \\
\text { pengunjung }\end{array}$ \\
\hline $\begin{array}{c}\text { Rabu, } 25 \\
\text { April } 2018\end{array}$ & $\begin{array}{c}37 \\
\text { pengunjung }\end{array}$ & $\begin{array}{l}\text { Jumat, } 25 \\
\text { Mei } 2018\end{array}$ & $\begin{array}{c}23 \\
\text { pengunjung }\end{array}$ \\
\hline $\begin{array}{c}\text { Kamis, } 26 \\
\text { April } 2018\end{array}$ & $\begin{array}{c}29 \\
\text { pengunjung }\end{array}$ & $\begin{array}{c}\text { Sabtu, } 26 \text { Mei } \\
2018\end{array}$ & $\begin{array}{c}15 \\
\text { pengunjung }\end{array}$ \\
\hline $\begin{array}{c}\text { Jumat, } 27 \\
\text { April } 2018\end{array}$ & $\begin{array}{c}15 \\
\text { pengunjung }\end{array}$ & $\begin{array}{c}\text { Minggu, } 27 \\
\text { Mei } 2018\end{array}$ & $\begin{array}{c}17 \\
\text { pengunjung }\end{array}$ \\
\hline $\begin{array}{c}\text { Sabtu, } 28 \\
\text { April } 2018\end{array}$ & $\begin{array}{c}12 \\
\text { pengunjung }\end{array}$ & $\begin{array}{c}\text { Senin, } 28 \text { Mei } \\
2018\end{array}$ & $\begin{array}{c}39 \\
\text { pengunjung }\end{array}$ \\
\hline $\begin{array}{l}\text { Minggu, } 29 \\
\text { April } 2018\end{array}$ & $\begin{array}{c}38 \\
\text { pengunjung }\end{array}$ & $\begin{array}{l}\text { Selasa, } 29 \\
\text { Mei } 2018\end{array}$ & $\begin{array}{c}31 \\
\text { pengunjung }\end{array}$ \\
\hline $\begin{array}{c}\text { Senin, } 30 \\
\text { April } 2018\end{array}$ & $\begin{array}{c}21 \\
\text { pengunjung }\end{array}$ & $\begin{array}{c}\text { Rabu, } 30 \text { Mei } \\
2018\end{array}$ & $\begin{array}{c}33 \\
\text { pengunjung }\end{array}$ \\
\hline & & $\begin{array}{l}\text { Kamis, } 31 \\
\text { Mei } 2018\end{array}$ & $\begin{array}{c}36 \\
\text { pengunjung }\end{array}$ \\
\hline
\end{tabular}

\section{A. Ruang Perpustakaan}

Bulan April - mei 2018

Tabel 3. Data Perpustakaan 1

\begin{tabular}{cccc}
\hline Hari / & Jumlah & Hari / & Jumlah \\
Tanggal & & Tanggal & \\
\hline Minggu, 1 & 31 & Selasa, 1 Mei & 24 \\
April 2018 & pengunjung & 2018 & pengunjung \\
\hline Senin, 2 & 23 & Rabu, 2 Mei & 12 \\
April 2018 & pengunjung & 2018 & pengunjung \\
\hline Selasa, 3 & 36 & Kamis, 3 Mei & 14 \\
April 2018 & pengunjung & 2018 & pengunjung \\
\hline Rabu, 4 & 34 & Jumat, 4 Mei & 27 \\
April 2018 & pengunjung & 2018 & pengunjung \\
\hline Kamis, 5 & 25 & Sabtu, 5 Mei & 43 \\
April 2018 & pengunjung & 2018 & pengunjung \\
\hline Jumat, 6 & 41 & Minggu, 6 & 32 \\
April 2018 & pengunjung & Mei 2018 & pengunjung \\
\hline Sabtu, 7 & 25 & Senin, 7 Mei & 41 \\
April 2018 & pengunjung & 2018 & pengunjung \\
\hline & & &
\end{tabular}

Sumber: (Wardiani \& Merlina, 2018)

\section{B. Ruang Bermain}

Bulan April - mei 2018

Tabel 5. Data Bermain 1

\begin{tabular}{cccc}
\hline Hari / Tanggal & Jumlah & $\begin{array}{c}\text { Hari / } \\
\text { Tanggal }\end{array}$ & Jumlah \\
\hline Minggu, 1 April & 32 & Selasa, 1 & 23 \\
2018 & pengunjung & Mei 2018 & pengunjung \\
\hline Senin, 2 April & 24 & Rabu, 2 Mei & 24 \\
2018 & pengunjung & 2018 & pengunjung \\
\hline Selasa, 3 April & 38 & Kamis, 3 & 14 \\
2018 & pengunjung & Mei 2018 & pengunjung \\
\hline Rabu, 4 April & 31 & Jumat, 4 & 27 \\
2018 & pengunjung & Mei 2018 & pengunjung \\
\hline Kamis, 5 April & 32 & Sabtu, 5 & 36 \\
2018 & pengunjung & Mei 2018 & pengunjung \\
\hline Jumat, 6 April & 13 & Minggu, 6 & 21 \\
\hline
\end{tabular}




\begin{tabular}{|c|c|c|c|}
\hline Hari / Tanggal & Jumlah & $\begin{array}{c}\text { Hari / } \\
\text { Tanggal }\end{array}$ & Jumlah \\
\hline 2018 & pengunjung & Mei 2018 & pengunjung \\
\hline $\begin{array}{c}\text { Sabtu, } 7 \text { April } \\
2018 \\
\end{array}$ & $\begin{array}{c}26 \\
\text { pengunjung }\end{array}$ & $\begin{array}{c}\text { Senin, } 7 \text { Mei } \\
2018 \\
\end{array}$ & $\begin{array}{c}31 \\
\text { pengunjung }\end{array}$ \\
\hline $\begin{array}{c}\text { Minggu, 8 April } \\
2018 \\
\end{array}$ & $\begin{array}{c}35 \\
\text { pengunjung }\end{array}$ & $\begin{array}{c}\text { Selasa, } 8 \\
\text { Mei } 2018\end{array}$ & $\begin{array}{c}22 \\
\text { pengunjung }\end{array}$ \\
\hline $\begin{array}{c}\text { Senin, } 9 \text { April } \\
2018\end{array}$ & $\begin{array}{c}21 \\
\text { pengunjung }\end{array}$ & $\begin{array}{c}\text { Rabu, 9 Mei } \\
2018 \\
\end{array}$ & $\begin{array}{c}13 \\
\text { pengunjung }\end{array}$ \\
\hline $\begin{array}{c}\text { Selasa, } 10 \text { April } \\
2018 \\
\end{array}$ & $\begin{array}{c}26 \\
\text { pengunjung }\end{array}$ & $\begin{array}{l}\text { Kamis, } 10 \\
\text { Mei } 2018 \\
\end{array}$ & $\begin{array}{c}12 \\
\text { pengunjung }\end{array}$ \\
\hline $\begin{array}{c}\text { Rabu, 11 April } \\
2018\end{array}$ & $\begin{array}{c}36 \\
\text { pengunjung }\end{array}$ & $\begin{array}{l}\text { Jumat, } 11 \\
\text { Mei } 2018\end{array}$ & $\begin{array}{c}37 \\
\text { pengunjung }\end{array}$ \\
\hline $\begin{array}{c}\text { Kamis, } 12 \text { April } \\
2018\end{array}$ & $\begin{array}{c}12 \\
\text { pengunjung }\end{array}$ & $\begin{array}{l}\text { Sabtu, } 12 \\
\text { Mei } 2018\end{array}$ & $\begin{array}{c}26 \\
\text { pengunjung }\end{array}$ \\
\hline $\begin{array}{c}\text { Jumat, } 13 \text { April } \\
2018 \\
\end{array}$ & $\begin{array}{c}14 \\
\text { pengunjung }\end{array}$ & $\begin{array}{c}\text { Minggu, } 13 \\
\text { Mei } 2018 \\
\end{array}$ & $\begin{array}{c}32 \\
\text { pengunjung }\end{array}$ \\
\hline $\begin{array}{c}\text { Sabtu, 14 April } \\
2018\end{array}$ & $\begin{array}{c}40 \\
\text { pengunjung }\end{array}$ & $\begin{array}{l}\text { Senin, } 14 \\
\text { Mei } 2018\end{array}$ & $\begin{array}{c}35 \\
\text { pengunjung }\end{array}$ \\
\hline $\begin{array}{c}\text { Minggu, } 15 \text { April } \\
2018 \\
\end{array}$ & $\begin{array}{c}31 \\
\text { pengunjung }\end{array}$ & $\begin{array}{l}\text { Selasa, } 15 \\
\text { Mei } 2018 \\
\end{array}$ & $\begin{array}{c}38 \\
\text { pengunjung }\end{array}$ \\
\hline $\begin{array}{c}\text { Senin, } 16 \text { April } \\
2018 \\
\end{array}$ & $\begin{array}{c}25 \\
\text { pengunjung }\end{array}$ & $\begin{array}{l}\text { Rabu, } 16 \\
\text { Mei } 2018 \\
\end{array}$ & $\begin{array}{c}21 \\
\text { pengunjung }\end{array}$ \\
\hline $\begin{array}{c}\text { Selasa, } 17 \text { April } \\
2018 \\
\end{array}$ & $\begin{array}{c}37 \\
\text { pengunjung }\end{array}$ & $\begin{array}{l}\text { Kamis, } 17 \\
\text { Mei } 2018\end{array}$ & $\begin{array}{c}26 \\
\text { pengunjung }\end{array}$ \\
\hline $\begin{array}{c}\text { Rabu, 18 April } \\
2018\end{array}$ & $\begin{array}{c}24 \\
\text { pengunjung }\end{array}$ & $\begin{array}{l}\text { Jumat, } 18 \\
\text { Mei } 2018\end{array}$ & $\begin{array}{c}34 \\
\text { pengunjung }\end{array}$ \\
\hline $\begin{array}{c}\text { Kamis, } 19 \text { April } \\
2018 \\
\end{array}$ & $\begin{array}{c}29 \\
\text { pengunjung }\end{array}$ & $\begin{array}{l}\text { Sabtu, } 19 \\
\text { Mei } 2018\end{array}$ & $\begin{array}{c}32 \\
\text { pengunjung }\end{array}$ \\
\hline $\begin{array}{c}\text { Jumat, } 20 \text { April } \\
2018 \\
\end{array}$ & $\begin{array}{c}31 \\
\text { pengunjung }\end{array}$ & $\begin{array}{c}\text { Minggu, } 20 \\
\text { Mei } 2018 \\
\end{array}$ & $\begin{array}{c}25 \\
\text { pengunjung }\end{array}$ \\
\hline $\begin{array}{c}\text { Sabtu, 21 April } \\
2018\end{array}$ & $\begin{array}{c}32 \\
\text { pengunjung }\end{array}$ & $\begin{array}{l}\text { Senin, } 21 \\
\text { Mei } 2018\end{array}$ & $\begin{array}{c}29 \\
\text { pengunjung }\end{array}$ \\
\hline $\begin{array}{c}\text { Minggu, } 22 \text { April } \\
2018 \\
\end{array}$ & $\begin{array}{c}33 \\
\text { pengunjung }\end{array}$ & $\begin{array}{l}\text { Selasa, } 22 \\
\text { Mei } 2018 \\
\end{array}$ & $\begin{array}{c}39 \\
\text { pengunjung }\end{array}$ \\
\hline $\begin{array}{c}\text { Senin, } 23 \text { April } \\
2018 \\
\end{array}$ & $\begin{array}{c}32 \\
\text { pengunjung }\end{array}$ & $\begin{array}{l}\text { Rabu, 23 } \\
\text { Mei } 2018 \\
\end{array}$ & $\begin{array}{c}16 \\
\text { pengunjung }\end{array}$ \\
\hline $\begin{array}{c}\text { Selasa, 24 April } \\
2018\end{array}$ & $\begin{array}{c}21 \\
\text { pengunjung }\end{array}$ & $\begin{array}{l}\text { Kamis, } 24 \\
\text { Mei } 2018\end{array}$ & $\begin{array}{c}18 \\
\text { pengunjung }\end{array}$ \\
\hline $\begin{array}{c}\text { Rabu, } 25 \text { April } \\
2018 \\
\end{array}$ & $\begin{array}{c}24 \\
\text { pengunjung }\end{array}$ & $\begin{array}{l}\text { Jumat, } 25 \\
\text { Mei } 2018 \\
\end{array}$ & $\begin{array}{c}24 \\
\text { pengunjung }\end{array}$ \\
\hline $\begin{array}{c}\text { Kamis, } 26 \text { April } \\
2018\end{array}$ & $\begin{array}{c}36 \\
\text { pengunjung }\end{array}$ & $\begin{array}{l}\text { Sabtu, } 26 \\
\text { Mei } 2018 \\
\end{array}$ & $\begin{array}{c}21 \\
\text { pengunjung }\end{array}$ \\
\hline $\begin{array}{c}\text { Jumat, } 27 \text { April } \\
2018\end{array}$ & $\begin{array}{c}39 \\
\text { pengunjung }\end{array}$ & $\begin{array}{l}\text { Minggu, } 27 \\
\text { Mei } 2018\end{array}$ & $\begin{array}{c}35 \\
\text { pengunjung }\end{array}$ \\
\hline $\begin{array}{c}\text { Sabtu, } 28 \text { April } \\
2018 \\
\end{array}$ & $\begin{array}{c}12 \\
\text { pengunjung }\end{array}$ & $\begin{array}{l}\text { Senin, } 28 \\
\text { Mei } 2018 \\
\end{array}$ & $\begin{array}{c}32 \\
\text { pengunjung }\end{array}$ \\
\hline $\begin{array}{c}\text { Minggu, } 29 \text { April } \\
2018 \\
\end{array}$ & $\begin{array}{c}33 \\
\text { pengunjung }\end{array}$ & $\begin{array}{l}\text { Selasa, } 29 \\
\text { Mei } 2018 \\
\end{array}$ & $\begin{array}{c}37 \\
\text { pengunjung }\end{array}$ \\
\hline $\begin{array}{c}\text { Senin, } 30 \text { April } \\
2018\end{array}$ & $\begin{array}{c}25 \\
\text { pengunjung }\end{array}$ & $\begin{array}{l}\text { Rabu, } 30 \\
\text { Mei } 2018\end{array}$ & $\begin{array}{c}32 \\
\text { pengunjung }\end{array}$ \\
\hline & & $\begin{array}{l}\text { Kamis, } 31 \\
\text { Mei 2018 }\end{array}$ & $\begin{array}{c}15 \\
\text { pengunjung }\end{array}$ \\
\hline
\end{tabular}

Sumber: (Wardiani \& Merlina, 2018)

\section{HASIL DAN PEMBAHASAN}

Berikut ini merupakan skema proses pengolahan data menggunakan K-Means, yaitu :

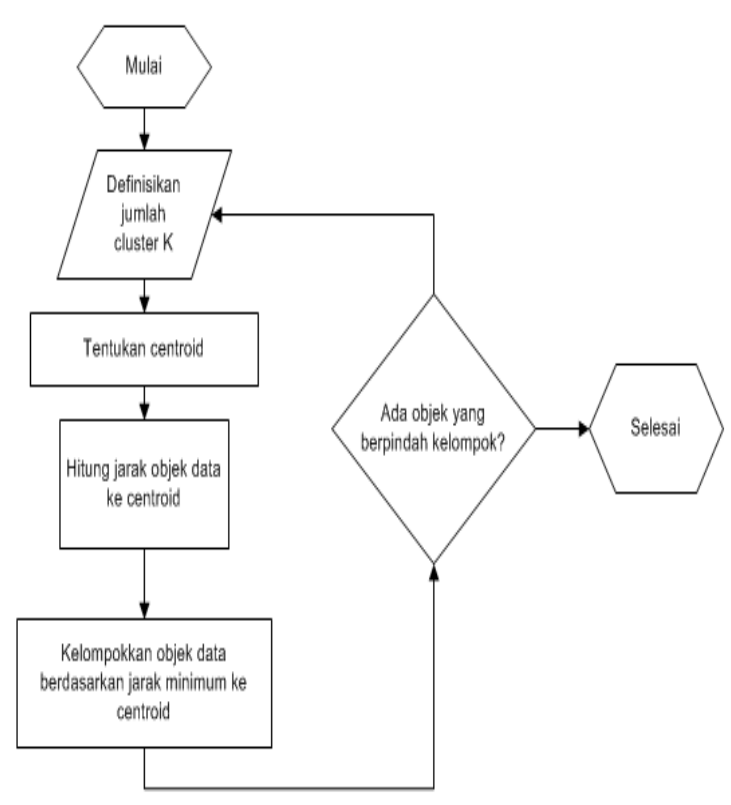

Sumber: (Wardiani \& Merlina, 2018)

Gambar 2. Skema Algoritma K-Means

\section{Transformasi Data}

Transformasi data pengunjung dibuat disatukan selama 2 bulan dalam satu tabel, hari/tanggal diubah menjadi nomor urut dan menambahkan atribut rata-rata dari jumlah pengunjung selama 2 bulan dibagi 8 minggu, seperti pada tabel dibawah ini :

Table 7.Contoh Transformasi Data Ruang Aula

\begin{tabular}{ccc}
\hline No & Jumlah & Rata-rata \\
\hline 1 & 32 & 4,00 \\
\hline 2 & 36 & 4,50 \\
\hline 3 & 41 & 5,13 \\
\hline
\end{tabular}

Sumber: (Wardiani \& Merlina, 2018)

Table 8. Contoh Transformasi Data Ruang Perpustakaan

\begin{tabular}{ccc}
\multicolumn{3}{c}{ Ruang Perpustakaan } \\
\hline No & Jumlah & Rata-rata \\
\hline 1 & 31 & 3,88 \\
\hline 2 & 23 & 2,88 \\
\hline 3 & 36 & 4,50 \\
\hline
\end{tabular}

Sumber: (Wardiani \& Merlina, 2018)

Table 9. Contoh Transformasi Data Ruang Bermain

\begin{tabular}{ccc}
\hline No & Jumlah & Rata-rata \\
\hline 1 & 32 & 4,00 \\
\hline 2 & 24 & 3,00 \\
\hline 3 & 38 & 4,75 \\
\hline
\end{tabular}

Sumber: (Wardiani \& Merlina, 2018) 
Pengukuran jarak yang digunakan adalah jarak Euclidean Distance. Jumlah cluster (K) adalah 3 yaitu cluster pertama produk untuk jumlah sedikit, cluster kedua untuk jumlah sedang dan cluster ketiga untuk jumlah banyak.

\section{Inisialisasi Data}

a. Ruang Aula

Dilakukan pemilihan $\mathrm{K}$ data sebagai centroid awal secara acak yaitu dipilih data ke- 28, 4, dan 12.

Table 10. Contoh Centroid Awal Aula

\begin{tabular}{ccc}
\hline Centroid & $\mathbf{X}$ & $\mathbf{Y}$ \\
\hline $\mathbf{1 .}$ & 12 & 1.50 \\
\hline $\mathbf{2 .}$ & 38 & 4,75 \\
\hline 3. & 121 & 15,125 \\
\hline
\end{tabular}

Sumber: (Wardiani \& Merlina, 2018)

b. Ruang Perpustakaan

Dilakukan pemilihan $\mathrm{K}$ data sebagai centroid awal secara acak yaitu dipilih data ke- 51, 36, dan 20.

c. Ruang Bermain

Dilakukan pemilihan $\mathrm{K}$ data sebagai centroi awal secara acak yaitu dipilihh data ke-13, 7, dan 14.

\section{d. Iterasi}

Mengihitung jarak setiap data ke centroid terdekat. Centroid terdekat akan menjadi claster yang diikut oleh data tersebut. Berikut penulis melakukan perhitungan dengan data ruang aula terlebih dahulu. Rumus Euclidean distance:

$d\left(x_{j}, c_{j}\right)=\sqrt{\sum_{j=1}^{n}\left(x_{j},-c_{j}\right)^{2}}$

Dimana: $\mathrm{d}=$ jarak; J= banyaknya data; $\mathrm{c}=$ centroid; $\mathrm{X}=$ data

\section{A. Cluster untuk Ruang Aula} adalah

Jarak centroid data ke 1 pada cluster 1

$$
\begin{aligned}
& d\left(x_{j}, c_{j}\right) \\
& =\sqrt{\sum_{j=1}^{n}\left(x_{j}-c_{j}\right)^{2}}=\sqrt{(32-12)^{2}+(4,00-1,5)^{2}} \\
& =\sqrt{400+6,25}=20,16
\end{aligned}
$$

Dimana:
32 = jumlah dari transformasi data ruang aula (data 1)

$12=\mathrm{x}$ dari centroid awal ruang aula

$4,00=$ rata-rata dari transformasi data ruang aula (data 1)

1,5 = y dari centroid awal ruang aula

Untuk jarak centroid selanjutnya dapat dilihat pada tabel berikut :

Tabel 11. Jarak Centroid Iterasi 1

\begin{tabular}{cccccc}
\hline $\mathbf{N}$ & $\mathbf{1}$ & $\mathbf{2}$ & $\mathbf{3}$ & $\begin{array}{c}\text { Jarak } \\
\text { terdekat }\end{array}$ & $\begin{array}{c}\text { Centroid } \\
\text { yg diikuti }\end{array}$ \\
\hline 1 & 20,16 & 6,05 & 89,69 & 6,05 & 2 \\
\hline 2 & 24,19 & 2,02 & 85,66 & 2,02 & 2 \\
\hline 3 & 29,23 & 3,02 & 80,62 & 3,02 & 2 \\
\hline
\end{tabular}

Sumber: (Wardiani \& Merlina, 2018)

Selanjutnya dihitung centroid yang baru untuk setiap cluster berdasarkan data yang

\begin{tabular}{|c|c|c|c|}
\hline & Data & $\mathbf{x}$ & $\mathbf{y}$ \\
\hline & 13 & 14 & 1,75 \\
\hline & 16 & 25 & 3,13 \\
\hline & 28 & 12 & 1,50 \\
\hline & 32 & 24 & 3,00 \\
\hline & 33 & 14 & 1,75 \\
\hline & 34 & 24 & 3,00 \\
\hline & 36 & 21 & 2,63 \\
\hline & 42 & 20 & 2,50 \\
\hline & 46 & 26 & 3,25 \\
\hline & 53 & 21 & 2,63 \\
\hline & 55 & 24 & 3,00 \\
\hline & 56 & 23 & 2,88 \\
\hline Jumlah & 12 & 248 & 31,00 \\
\hline Rata-rata & & 20,67 & 2,58 \\
\hline
\end{tabular}
tergabung pada setiap clusternya.

Table 12. Data Cluster 1 Iterasi 1

Table 13. Data Cluster 2 Iterasi 1

\begin{tabular}{ccc}
\hline Data & X & $Y$ \\
\hline 1 & 32 & 4,00 \\
\hline 2 & 36 & 4,50 \\
\hline 3 & 41 & 5,13 \\
\hline 4 & 38 & 4,75 \\
\hline 5 & 33 & 4,13 \\
\hline 6 & 45 & 5,63 \\
\hline 7 & 29 & 3,63 \\
\hline 8 & 39 & 4,88 \\
\hline 9 & 29 & 3,63 \\
\hline 10 & 26 & 3,25 \\
\hline 11 & 36 & 4,50 \\
\hline 14 & 40 & 5,00
\end{tabular}




\begin{tabular}{|c|c|c|c|}
\hline & 15 & 51 & 6,38 \\
\hline & 17 & 37 & 4,63 \\
\hline & 18 & 29 & 3,63 \\
\hline & 19 & 29 & 3,63 \\
\hline & 20 & 60 & 7,50 \\
\hline & 21 & 32 & 4,00 \\
\hline & 22 & 37 & 4,63 \\
\hline & 23 & 59 & 7,38 \\
\hline & 24 & 56 & 7,00 \\
\hline & 25 & 57 & 7,13 \\
\hline & 26 & 32 & 4,00 \\
\hline & 27 & 65 & 8,13 \\
\hline & 29 & 46 & 5,75 \\
\hline & 30 & 52 & 6,50 \\
\hline & 31 & 33 & 4,13 \\
\hline & 35 & 46 & 5,75 \\
\hline & 37 & 41 & 5,13 \\
\hline & 38 & 62 & 7,75 \\
\hline & 39 & 33 & 4,13 \\
\hline & 40 & 52 & 6,50 \\
\hline & 41 & 37 & 4,63 \\
\hline & 43 & 51 & 6,38 \\
\hline & 44 & 46 & 5,75 \\
\hline & 45 & 48 & 6,00 \\
\hline & 47 & 29 & 3,63 \\
\hline & 48 & 60 & 7,50 \\
\hline & 49 & 34 & 4,25 \\
\hline & 50 & 47 & 5,88 \\
\hline & 51 & 59 & 7,38 \\
\hline & 52 & 52 & 6,50 \\
\hline & 54 & 43 & 5,38 \\
\hline & 57 & 41 & 5,13 \\
\hline & 58 & 57 & 7,13 \\
\hline & 59 & 38 & 4,75 \\
\hline & 60 & 31 & 3,88 \\
\hline & 61 & 42 & 5,25 \\
\hline Jumlah & 48 & 2048 & 256,00 \\
\hline Rata-rata & & 42,67 & 5,33 \\
\hline
\end{tabular}

Table 14. Data Cluster 3 Iterasi 1

\begin{tabular}{|c|c|c|c|}
\hline & \multirow[t]{2}{*}{ Data } & $X$ & $\mathrm{Y}$ \\
\hline & & 121 & 15,13 \\
\hline Jumlah & 12 & 121 & 15,13 \\
\hline Rata-rata & & 121 & 15,13 \\
\hline \multicolumn{4}{|c|}{ Sumber: (Wardiani \& Merlina, 2018) } \\
\hline \multicolumn{4}{|c|}{$\begin{array}{l}\text { Lanjut hingga data tidak mengalami perubahan } \\
\text { atau berpindah cluster. Data ruang aula berhenti } \\
\text { pada iterasi ke- } 9 \text {. Berikut hasil iterasi ke } 9 \text { : }\end{array}$} \\
\hline
\end{tabular}

Table 15. Jarak Centroid Iterasi 9

\begin{tabular}{cccccc}
\hline $\mathbf{N}$ & $\mathbf{1}$ & $\mathbf{2}$ & $\mathbf{3}$ & $\begin{array}{c}\text { Jarak } \\
\text { terdekat }\end{array}$ & $\begin{array}{c}\text { Centroid } \\
\text { yg diikuti }\end{array}$ \\
$\mathbf{0}$ & 3,29 & 18,88 & 89,69 & 3,29 & 1 \\
2 & 7,32 & 14,84 & 85,66 & 7,32 & 1 \\
3 & 12,36 & 9,81 & 80,62 & 9,81 & 2 \\
\hline
\end{tabular}

Sumber: (Wardiani \& Merlina, 2018)

Table 16. Data Cluster 1 Iterasi 9

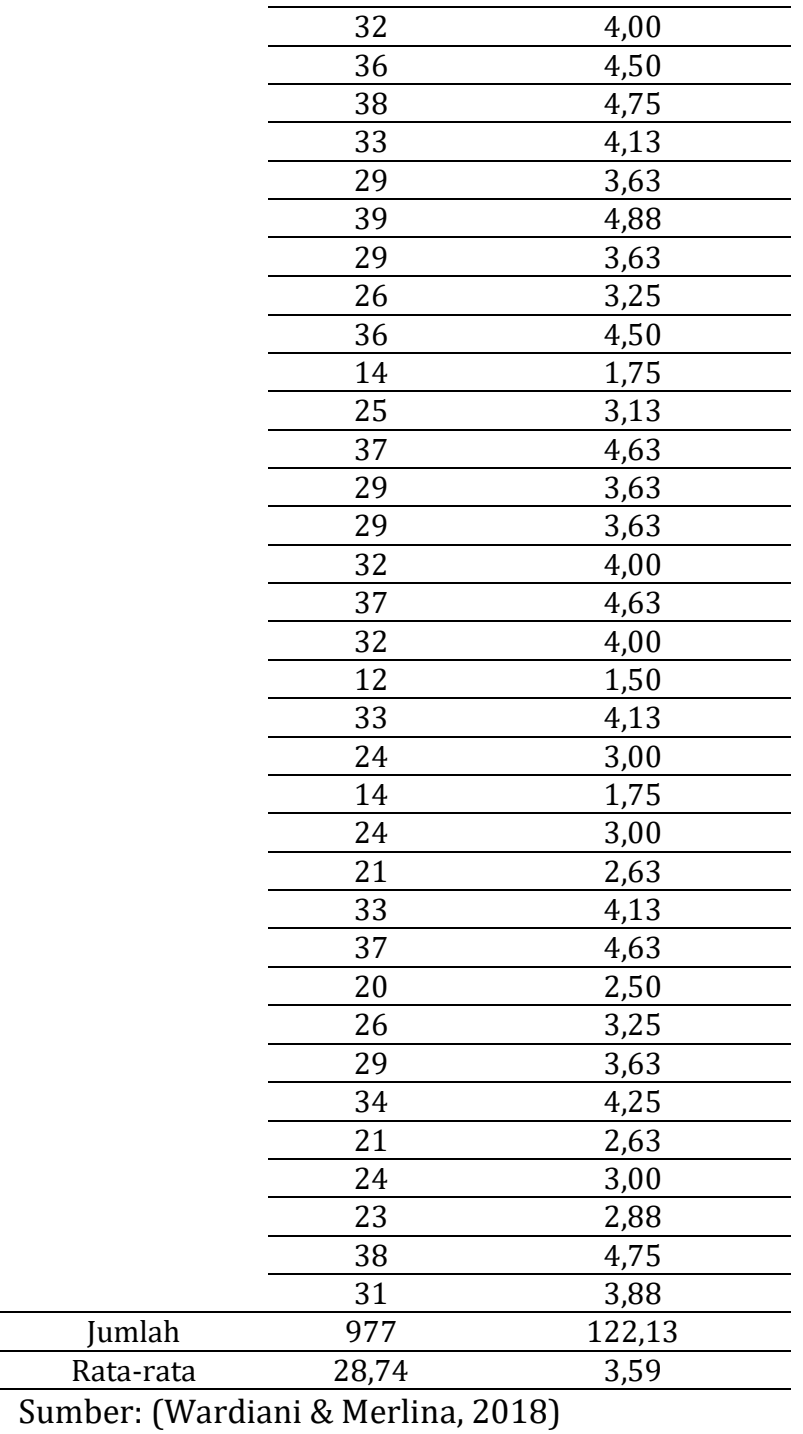

Table 17. Data Cluster 2 Iterasi 9

\begin{tabular}{ll}
\hline 41 & 5,13 \\
\hline 45 & 5,63 \\
\hline 40 & 5,00 \\
\hline 51 & 6,38 \\
\hline 60 & 7,50 \\
\hline 59 & 7,38 \\
\hline 56 & 7,00 \\
\hline 57 & 7,13 \\
\hline 65 & 8,13 \\
\hline 46 & 5,75 \\
\hline 52 & 6,50 \\
\hline 46 & 5,75 \\
\hline 41 & 5,13 \\
\hline 62 & 7,75 \\
\hline 52 & 6,50 \\
\hline 51 & 6,38 \\
\hline 46 & 5,75 \\
\hline 48 & 6,00 \\
\hline
\end{tabular}




\begin{tabular}{ccc}
\cline { 2 - 3 } & 60 & 7,50 \\
\cline { 2 - 3 } & 47 & 5,88 \\
\cline { 2 - 3 } & 59 & 7,38 \\
\cline { 2 - 3 } & 52 & 6,50 \\
\cline { 2 - 3 } & 43 & 5,38 \\
\cline { 2 - 3 } & 41 & 5,13 \\
\hline Jumlah & 42 & 7,13 \\
\hline Rata-rata & 50,73 & 5,25 \\
\hline Sumber: (Ward & 6,34 \\
\hline
\end{tabular}

Sumber: (Wardiani \& Merlina, 2018)

Table 18. Data Cluster 3 Iterasi 9

\begin{tabular}{lll}
\cline { 2 - 3 } & 121 & 15,13 \\
\hline Jumlah & 121 & 15,13 \\
\hline Rata-rata & 121 & 15,13 \\
\hline
\end{tabular}

Sumber: (Wardiani \& Merlina, 2018)

A. Hasil dari perhitungan ruang aula adalah : Untuk Cluster 1 atau cluster dengan nilai paling kecil dari data ruang aula adalah sebanyak 977 pengunjung. Untuk Cluster 2 atau cluster dengan nilai sedang dari data ruang aula adalah sebanyak 1319 . Dan untuk Cluster 3 atau cluster dengan nilai besar dari data ruang aula adalah sebanyak 121 pengunjung.

B. Hasil dari perhitungan ruang perpustakaan adalah :

Untuk Cluster 1 atau cluster dengan nilai paling kecil dari data ruang aula adalah sebanyak 531 pengunjung. Untuk Cluster 2 atau cluster dengan nilai sedang dari data ruang aula adalah sebanyak 713. Dan untuk Cluster 3 atau cluster dengan nilai besar dari data ruang aula adalah sebanyak 518 pengunjung.

C. Hasil dari perhitungan ruang bermain adalah: Untuk Cluster 1 atau cluster dengan nilai paling kecil dari data ruang aula adalah sebanyak 139 pengunjung. Untuk Cluster 2 atau cluster dengan nilai sedang dari data ruang aula adalah sebanyak 509. Dan untuk Cluster 3 atau cluster dengan nilai besar dari data ruang aula adalah sebanyak 1033 pengunjung.

D. Hasil keseluruhan dari perhitungan 3 data pengunjung yaitu ruang aula, ruang perpustakaan dan ruang bermain pada RPTRA Kampung Benda dengan penulis mengambil jumlah cluster ke 2 dalam setiap data menghasilkan ruang aula 1319 pengunjung, ruang perpustakaan 713 pengunjung dan ruang bermain 509 pengunjung. Ruangan yang paling sering dipilih oleh pengunjung yaitu ruang aula.

\section{KESIMPULAN}

Hipotesa $\mathrm{H}_{0}$ dapat diterima oleh masyarakat Kampung Benda menggunakan metode K-Means Clustering. Dengan hasil ruang aula adalah ruangan yang paling sering dikunjungi. Dengan perhitungan data mining dan dibantu oleh Software pendukung (Microsoft Excel) dalam mengolah data dapat merubah cara penyimpanan arsip menjadi lebih efisien. Pengunjung pada RPTRA Kampung Benda ini sudah ada beberapa yang mengetahui terdapat fasilitas-fasilitas dan ruangan-ruangan apa saja di RPTRA ini. Metode KMeans Clustering ini dapat membantu petugas dan pemerintah untuk mengetahui seberapa manfaat RPTRA yang ada sekarang ini, dengan melihat data dan dapat membuat grafik pengunjung setiap bulan atau setiap tahunnya. Ruang aula merupakan ruangan yang sering dikunjingi dari aspek manajerial, penelitian ini dapat dikembangkan lagi dengan menggunakan perhitungan lainnya atau metode lainnya yang lebih akurat. Hasil penelitian ini adalah ruang aula yg memiliki nilai tertinggi untuk pengunjung yang dating dimana nilai yang didapat adalah 1319 pengunjung .

\section{REFERENSI}

Dhuhita, W. M. P. (2016). Clustering Menggunakan Metode K-Means untuk Menentukan Status Gizi Balita. .. Jurnal Informatika, Vol.2, 160174.

Indah, A. S. K., Wardiyati, T., \& Setyobudi, L. (2014). ANALISA LANSKAP JALUR HIJAU DAN UPAYA PENERAPAN SMART GREEN LAND PADA RUANG TERBUKA HIJAU. Jurnal Produksi Tanaman, 2(3). https://doi.org/10.21176/PROTAN.V2I3.97

Prasetyowati, E., \& Rofiq, A. A. (2016). PENILAIAN KINERJA KEUANGAN KOPERASI PADA DINAS KOPERASI DAN UMKM PAMEKASAN DENGAN K-MEANS. Jurnal Simantec, 5(2), 67-74. Retrieved from http://neobis.trunojoyo.ac.id/simantec/article/view/1 591

Rosyidin, W. F., Giyanti, S., \& Dahlia, S. (2017). Analisis Spasial Ruang Publik Terpadu Ramah Anak (RPTRA) "Puspita" sebagai Urban Resilience di Kelurahan Pesanggrahan Jakarta Selatan. Jurnal Geografi Edukasi Dan Lingkungan, Vol.1, 19-26.

Sanitya, R. S., \& Burhanudin, H. (2013). PENENTUAN LOKASI DAN JUMLAH LUBANG 
RESAPAN BIOPORI DI KAWASAN DAS CIKAPUNDUNG BAGIAN TENGAH. Jurnal Perencanaan Wilayah Dan Kota, 13(1), 1-14. Retrieved from https://ejournal.unisba.ac.id/index.php/pla nologi/article/view/1385

Sugiyono. (2014). Metode Penelitian Kombinasi (Mixed Method). Alfabeta.

Suwardika, G. (2017). PENGELOMPOKKAN DAN KLASIFIKASI PENGGUNAAN KONTRASEPSI DI INDONESIA. Jurnal Matematika, Sains, Dan Teknologi, 17(1), 9-19. Retrieved from http://ilp.ut.ac.id/index.php/JMST/article/v iew $/ 263$

Vulandari, R. T. (2017). Data Mining Teori dan Aplikasi Rapidminer. Yogyakarta: Gaava Media.

Wardiani, D. S., \& Merlina, N. (2018). Laporan Akhir Penelitian Mandiri. Jakarta.

Wicaksono Yudhy \& Solusi Kantor. (2017). Panduan Lengkap Menggunakan Excel 2016. Jakarta. PT. Elex Media Komputindo. 